\title{
Hydroclimatic regimes: a distributed water-balance framework for hydrologic assessment, classification, and management
}

\author{
P. K. Weiskel ${ }^{1}$, D. M. Wolock ${ }^{2}$, P. J. Zarriello ${ }^{1}$, R. M. Vogel ${ }^{1,3}$, S. B. Levin ${ }^{1}$, and R. M. Lent ${ }^{4}$ \\ ${ }^{1}$ US Geological Survey, Northborough, MA 01532, USA \\ ${ }^{2}$ US Geological Survey, Lawrence, KS 66049, USA \\ ${ }^{3}$ Department of Civil and Environmental Engineering, Tufts University, Medford, MA 02155, USA \\ ${ }^{4}$ US Geological Survey, Augusta, ME 04330, USA
}

Correspondence to: P. K. Weiskel (pweiskel@usgs.gov)

Received: 1 February 2014 - Published in Hydrol. Earth Syst. Sci. Discuss.: 11 March 2014

Revised: 3 August 2014 - Accepted: 7 August 2014 - Published: 1 October 2014

\begin{abstract}
Runoff-based indicators of terrestrial water availability are appropriate for humid regions, but have tended to limit our basic hydrologic understanding of drylands - the dry-subhumid, semiarid, and arid regions which presently cover nearly half of the global land surface. In response, we introduce an indicator framework that gives equal weight to humid and dryland regions, accounting fully for both vertical (precipitation + evapotranspiration) and horizontal (groundwater + surface-water) components of the hydrologic cycle in any given location - as well as fluxes into and out of landscape storage. We apply the framework to a diverse hydroclimatic region (the conterminous USA) using a distributed water-balance model consisting of 53400 networked landscape hydrologic units. Our model simulations indicate that about $21 \%$ of the conterminous USA either generated no runoff or consumed runoff from upgradient sources on a mean-annual basis during the 20th century. Vertical fluxes exceeded horizontal fluxes across $76 \%$ of the conterminous area. Long-term-average total water availability (TWA) during the 20th century, defined here as the total influx to a landscape hydrologic unit from precipitation, groundwater, and surface water, varied spatially by about 400000 -fold, a range of variation $\sim 100$ times larger than that for meanannual runoff across the same area. The framework includes but is not limited to classical, runoff-based approaches to water-resource assessment. It also incorporates and reinterprets the green- and blue-water perspective now gaining international acceptance. Implications of the new framework for several areas of contemporary hydrology are explored,
\end{abstract}

and the data requirements of the approach are discussed in relation to the increasing availability of gridded global climate, land-surface, and hydrologic data sets.

\section{Introduction}

Scarcity of freshwater for human and ecosystem needs is one of the critical global challenges of the 21 st century. Water scarcity, in any given location or hydrologic unit (Appendix A; online Supplement; Fig. 1a), may partly result from human interactions with the ground- and surface-water systems of the hydrologic unit (Vörösmarty and Sahagian, 2000; Weiskel et al., 2007; Hoekstra et al., 2012; Vörösmarty et al., 2013). Direct human-hydrologic interactions include water withdrawals, transfers, and return flows (Weiskel et al., 2007), while indirect human interactions include deforestation, urbanization, agricultural land use (Karimi et al., 2013; Lo and Famiglietti, 2013; Gerten, 2013), anthropogenic climate change (Milly et al., 2005; Hagemann et al., 2013), dam construction, river and wetland channelization, wetland filling, and other human processes (Vörösmarty et al., 2013). Patterns of water scarcity and availability may also reflect the baseline of hydroclimatic diversity that is largely independent of human effects. In fact, one of the principal ways in which the hydrologic community has responded to the contemporary water-scarcity challenge is by constructing climatically forced, spatially distributed, regional-to-global-scale water-balance models that simulate fundamental hydrologic 
processes such as runoff generation and streamflow under specified baseline conditions (e.g., Vörösmarty et al., 2000; Döll et al., 2003; Milly et al., 2005; Oki and Kanae, 2006; Röst et al., 2008; Hoff et al., 2010; Hagemann et al., 2013). Subsequently, these models have been used to simulate hydrologic responses to land-cover, water-use, and climate change, at a range of spatial and temporal scales.

It is important to note that the term "baseline" can no longer be equated, without qualification, with pristine, predevelopment, or long-term-average conditions, largely because of two recent insights on the part of the hydrologic community. First, it is now broadly understood that the Industrial Revolution launched a new period of earth's history - the Anthropocene epoch. During this epoch, human effects on the climate, the hydrosphere, and the land-surface portion of the earth system have become pervasive, though not necessarily equally distributed in space (Vogel, 2011; Vörösmarty et al., 2013; Savenije et al., 2014). The second insight is the renewed appreciation of the nonstationary component of hydrologic processes (Milly et al., 2008; Matalas, 2012; Rosner et al., 2014). In light of these developments, we use the term "baseline" in this paper to denote an explicitly specified period of observational record, or of model simulation, that can serve as a basis for comparison with other periods characterized by different climate, land-cover, or water-use conditions.

In order to facilitate comparative analysis and communication in the growing fields of comparative hydrology and global hydrology (Falkenmark and Chapman, 1989; Thompson et al., 2013), we suggest that a coherent new framework of quantitative water-availability indicators is needed. The purpose of this paper is to derive such a framework, using the landscape water-balance equation as the organizing principle. The framework is spatially and temporally distributed, compatible with existing water-balance models such as those cited above, and unbiased - in the sense of being equally applicable to humid and dryland (Appendix A) regions. Moreover, the framework is informed by both classical (runoffbased) and emerging perspectives on water availability, including the green- and blue-water paradigm now gaining acceptance in the water management community (Falkenmark and Rockström, 2004, 2006, 2010; cf. Special Issue, J. Hydrol., 384, 3-4, 2010). The green-blue paradigm contains critical insights, which we reinterpret for this paper. After deriving the new framework, we demonstrate it across a diverse hydroclimatic region (the conterminous USA). Finally, we discuss the implications of the framework for hydrologic assessment, classification, and management.

\section{Theoretical background}

\subsection{The landscape water balance}

The water balance of a hydrologic unit (Fig. 1a) may be stated as follows:

$$
\begin{aligned}
P(\Delta t) & +L_{\text {in }}(\Delta t)+H_{\text {in }}(\Delta t)=E_{\mathrm{T}}(\Delta t)+L_{\text {out }}(\Delta t) \\
& +H_{\text {out }}(\Delta t)+\mathrm{d} S_{\mathrm{T}} / \mathrm{d} t(\Delta t)
\end{aligned}
$$

where $P$ is precipitation, $L_{\text {in,out }}$ is saturated landscape (ground-water + surface-water) inflows to, and outflows from a hydrologic unit, $H_{\text {in,out }}=$ human inflows to and withdrawals from a hydrologic unit (Weiskel et al., 2007), $E_{\mathrm{T}}$ is evapotranspiration, and $\mathrm{d} S_{\mathrm{T}} / \mathrm{d} t=\left[\left(P+L_{\mathrm{in}}\right)-\left(E_{\mathrm{T}}+L_{\text {out }}\right)\right]$ is the rate of change (positive, negative, or zero) of total water storage in the soil moisture, groundwater, surface water, ice, snow, and human water infrastructure of the hydrologic unit - with all terms averaged over a time period (or step) of interest, $\Delta t$, in units of $\mathrm{L}^{3} \mathrm{~T}^{-1}$ per unit area of the hydrologic unit, or $\mathrm{L} \mathrm{T}^{-1}$ (see Table 2 ). Human flows $\left(H_{\text {in }}\right.$ and $\left.H_{\text {out }}\right)$ and the artificial component of total storage are initially set equal to zero for development of the baseline framework of the present paper.

\subsection{Green and blue water}

Water availability may be viewed from either an opensystem, hydrologic-unit spatial perspective (Fig. 1a) or from a semiclosed, catchment perspective (Fig. 1b, and Appendix A). Working within the catchment spatial context of Fig. 1b, Falkenmark and Rockström (2004, 2006, 2010) refer to the outflow terms $E_{\mathrm{T}}$ and $L_{\text {out }}$ as "green" and "blue" water flows, respectively, and explore the consequences of this distinction for land and water management. Precipitation, in their framework, is viewed as an undifferentiated inflow term, and is therefore symbolized by white arrows in Fig. 1b.

Working within the open-system, hydrologic-unit context of Eq. (1) and Fig. 1a, we reinterpret the green- and blue-water perspective as follows. We define both types of land-atmosphere water exchange with a hydrologic unit $\left(P\right.$ and $\left.E_{\mathrm{T}}\right)$ as green-water fluxes, and both types of horizontal flow through a hydrologic unit ( $L_{\text {in }}$ and $\left.L_{\text {out }}\right)$ as blue-water fluxes (Fig. 1a). Consistent with Falkenmark and Rockström (2004), we also make a clear distinction between green- and blue-water fluxes and green- and blue-water storage compartments. We follow these authors in defining the unsaturated (or vadose) zone above the water table as the green (or soil moisture) storage compartment of a hydrologic unit, and all saturated groundwater and surface-water zones, including accumulated ice and snow, as blue storage compartments. In summary, our reinterpretation of green- and blue-water terminology is intended to place the original definitions of Falkenmark and Rockström (2004, 2006, 2010) into a more general, open-system spatial context, whereby 
a

\section{Hydrologic unit:}

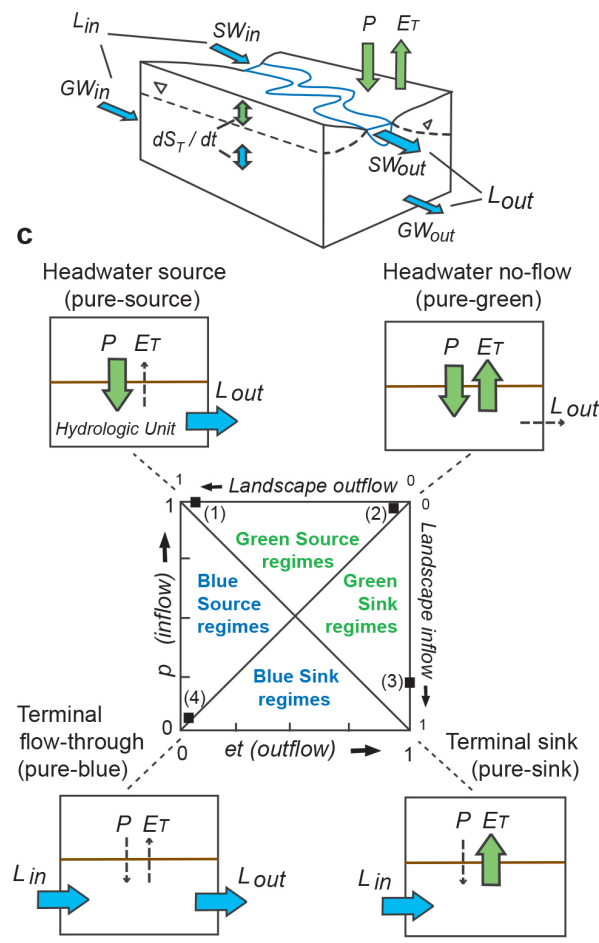

b

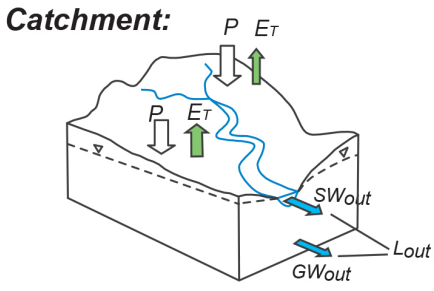

d
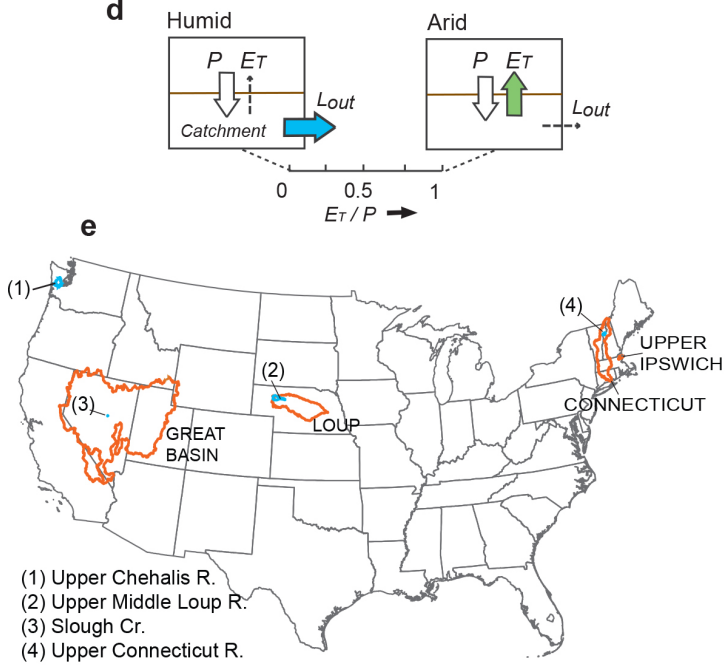

Figure 1. (a) Hydrologic unit, and (b) catchment, showing land-atmosphere (or green) fluxes (precipitation, evapotranspiration; $P, E_{\mathrm{T}}$ ) and landscape (or blue) fluxes (groundwater + surface-water flows; $L_{\mathrm{in}}, L_{\mathrm{out}}$ ) at boundaries. Double arrows show change in green (unsaturated) and blue (saturated) storage; their sum equals change in total water storage $\left(\mathrm{d} S_{\mathrm{T}} / \mathrm{d} t\right)$ during a time step of interest. Catchment $P$ influxes, defined by Falkenmark and Rockström (2004) as undifferentiated (neither green nor blue), indicated by white arrows. Internal soil moisture/ groundwater/surface-water exchanges not shown. (c) Hydroclimatic regime for a hydrologic unit is defined by the 2-D, (et, $p$ ) plotting position on central regime space; see Table 2 for et and $p$ definitions. End-member regimes shown by sketches at corners of regime space. Example regimes: sites 1, 2, 3, and 4; see Table 1. (d) Catchment hydroclimatic regime, defined by the 1-D position on $E_{\mathrm{T}} / P$ axis. (e) Location map for sites 1, 2, 3, and 4 (Table 1), and major basins (Sect. 4; Fig. 2).

both types of inflow to a hydrologic unit (landscape inflows and precipitation) are available for partition into blue and green outflows.

\subsection{Hydroclimatic regimes, total water availability, and regime indicators}

We define the hydroclimatic regime of a hydrologic unit as the particular combination of green- and blue-water-balance components that characterizes the baseline functioning of a particular hydrologic unit (of any size) averaged over a specific time step of interest (of any length). For the purposes of our initial theoretical analysis, human flows and artificial storage are excluded from consideration, as noted above, and green and blue storage changes are lumped into a total storage change term. Consistent with Milly et al. (2008), we also define hydroclimatic regimes in temporally explicit terms (i.e., for particular time periods or steps).

To facilitate the understanding of hydroclimatic regimes and the relative magnitudes of all water-balance compo- nents, it is useful to normalize each term in Eq. (1) to the total inflow available to a hydrologic unit during a time step (cf. Lent et al., 1997; Weiskel et al., 2007). We refer to this total inflow as the "total water availability" (TWA). TWA is defined, for a given time step, as the larger of two quantities: (1) inflow from local precipitation and upgradient landscape sources $\left(P+L_{\text {in }}\right)$, or (2) inflow from these sources plus "inflow" from depletion of internal storage. That is, TWA $=\max \left\{\left(P+L_{\text {in }}\right),\left(P+L_{\text {in }}+\left[-\mathrm{d} S_{\mathrm{T}} / \mathrm{d} t\right]\right)\right\}$ for a time step. As stated previously, the $\mathrm{d} S_{\mathrm{T}} / \mathrm{d} t$ term of Eq. (1) may be either positive, negative, or zero during a time step. Therefore, during periods when $\mathrm{d} S_{\mathrm{T}} / \mathrm{d} t$ is either zero (steady-state periods) or positive (accretion periods), TWA $=P+L_{\text {in }}$. When $\mathrm{d} S_{\mathrm{T}} / \mathrm{d} t$ is negative (depletion periods), TWA $=P+L_{\mathrm{in}}+\left[-\mathrm{d} S_{\mathrm{T}} / \mathrm{d} t\right]$. Normalization of Eq. (1) to TWA yields the following dimensionless form of the landscape water-balance equation, expressed in lowercase symbols, for conditions of storage accretion or zero change (Eq. 2a) and depletion (Eq. 2b), respectively: 
Table 1. Water-balance components and hydroclimatic regime indicators; sites 1,2,3, and 4 (Fig. 1e). The regime of each site approaches one of four end members shown in Fig. 1c. See Table 2 for indicator definitions. Mean-annual (1896-2006) water-balance components obtained from the distributed water-balance model of the conterminous USA (see Sect. 3). HUC-8 (eight-digit hydrologic-unit code; see Supplement); HU ID, hydrologic-unit identifier, water-balance model; DA, drainage area. $P$, precipitation; $E_{\mathrm{T}}$, evapotranspiration; $L_{\mathrm{in}}$, landscape (surface water + groundwater) inflow; $L_{\text {out }}$, landscape outflow; $\mathrm{d} S_{\mathrm{T}} / \mathrm{d} t$, change in total landscape storage; all fluxes are per unit area of the local $\mathrm{HU}$, in units of millimeters per year; rounded to 3 significant figures. The terms et and $p$ (normalized evapotranspiration and precipitation), et $/ p$, (hydrologic-unit $E_{\mathrm{T}}$ ratio), SSI (source-sink index), and GBI (green-blue index) are dimensionless; see Table 2.

\begin{tabular}{lrrrrrrrrrrrrr}
\hline $\begin{array}{l}\text { Hydrologic unit name, } \\
\text { location, and HUC-8 }\end{array}$ & $\begin{array}{r}\text { HU } \\
\text { ID }\end{array}$ & $\begin{array}{r}\mathrm{HU} \\
\mathrm{DA} \\
\mathrm{km}^{2}\end{array}$ & $\begin{array}{r}\mathrm{Up}- \\
\mathrm{gradient} \\
\mathrm{DA} \\
\mathrm{km}^{2}\end{array}$ & $\begin{array}{r}P \\
(\mathrm{~mm} \\
\left.\mathrm{yr}^{-1}\right)\end{array}$ & $\begin{array}{r}L_{\mathrm{in}} \\
\left.\mathrm{yr}^{-1}\right)\end{array}$ & $\begin{array}{r}E_{\mathrm{T}} \\
(\mathrm{mm} \\
\left.\mathrm{yr}^{-1}\right)\end{array}$ & $\begin{array}{r}L_{\mathrm{out}} \\
(\mathrm{mm} \\
\left.\mathrm{yr}^{-1}\right)\end{array}$ & $\begin{array}{r}\mathrm{d} S_{\mathrm{T}} / \mathrm{d} t \\
(\mathrm{~mm} \\
\left.\mathrm{yr}^{-1}\right)\end{array}$ & et & et/p & SSI & GBI \\
\hline $\begin{array}{l}\text { (1) Upper Chehalis River, } \\
\text { Washington (17100104) }\end{array}$ & 57994 & 44 & 0 & 6050 & 0 & 498 & 5540 & 0 & 0.08 & 1.00 & 0.08 & 0.92 & 0.54 \\
\hline $\begin{array}{l}\text { (2) Middle Loup River, } \\
\text { Nebraska (10210001) }\end{array}$ & 24038 & 1476 & 2853 & 532 & 19 & 519 & 32 & 0 & 0.94 & 0.97 & 0.95 & 0.02 & 0.98 \\
\hline $\begin{array}{l}\text { (3) Slough Creek, } \\
\text { Nevada (16060005) }\end{array}$ & 46385 & 20 & 2327 & 218 & 793 & 1010 & 0 & 0 & 1.00 & 0.22 & 4.63 & -0.78 & 0.61 \\
\hline $\begin{array}{l}\text { (4) Upper Connecticut R., } \\
\text { New Hampshire (01080101) }\end{array}$ & 1077 & 212 & 3996 & 957 & 11500 & 539 & 11900 & 0 & 0.04 & 0.08 & 0.56 & 0.03 & 0.06 \\
\hline
\end{tabular}

$p+l_{\text {in }}=\mathrm{et}+l_{\text {out }}+\mathrm{d} s_{\mathrm{T}} / \mathrm{d} t=1$, when $\left(\mathrm{d} s_{\mathrm{T}} / \mathrm{d} t>0\right) ;$

$p+l_{\text {in }}+\left[-\mathrm{d} s_{\mathrm{T}} / \mathrm{d} t\right]=\mathrm{et}+l_{\text {out }}=1$, when $\left(\mathrm{d} s_{\mathrm{T}} / \mathrm{d} t<0\right)$.

Each term in Eqs. (2a) and (2b) represents a fraction of the total water balance, and the fractions on each side of the equations sum to 1 . During periods of storage accretion $\left(\mathrm{d} s_{\mathrm{T}} / \mathrm{d} t>0\right.$; Eq. 2a), the total storage change term may be treated as an outflow to storage. During periods of storage depletion $\left(\mathrm{d} s_{\mathrm{T}} / \mathrm{d} t<0\right.$; Eq. $\left.2 \mathrm{~b}\right)$, the storage change term may be treated as an inflow from storage.

Hydroclimatic regimes may be represented graphically on plots of et versus $p$ (Fig. 1c, central square). This square regime space comprises the full diversity of potential hydroclimatic regimes found at earth's land surface; the corners of the plot correspond to end-member regimes where $p$ and et take on their limiting values. For example, at the headwater source end member (Fig. $1 \mathrm{c}$ ), $p=1$, et $=0, l_{\text {in }}=0$ and $l_{\text {out }}=1$. At the pure-green, headwater no-flow end member, $p=1$, et $=1, l_{\text {in }}=0$ and $l_{\text {out }}=0$. At the terminal sink end member, $p=0$, et $=1, l_{\text {in }}=1$ and $l_{\text {out }}=0$. Finally, at the pure-blue, terminal flow-through end member, $p=0$, et $=0$, $l_{\text {in }}=1$ and $l_{\text {out }}=1$. Example regimes $1-4$ (Fig. $1 \mathrm{c}$; with locations shown on Fig. 1e) approach the respective end members. See Table 1 for the water budgets and hydroclimatic indicators associated with example regimes $1-4$.

We use combinations of $p$ and et to define a new set of hydroclimatic indicators (Table 2): the green-blue index $(\mathrm{GBI}=[p+\mathrm{et}] / 2)$, the hydrologic-unit-evapotranspiration ratio $(\mathrm{et} / p)$, and the source/sink index $(\mathrm{SSI}=p-\mathrm{et})$. The GBI indicates the relative magnitudes of green $\left(P+E_{\mathrm{T}}\right)$ versus blue $\left(L_{\text {in }}+L_{\text {out }}\right)$ water fluxes experienced by a hydrologic unit during a period of interest (see Table 2). A hydrologic unit dominated by precipitation inflows and evapotran- spiration outflows (headwater no-flow end member; Fig. 1c) has a GBI near 1, while a hydrologic unit dominated by landscape flows (terminal flow-through end member) has a GBI near 0 . The remaining two indicators, SSI and et $/ p$, differentiate runoff-generating source regimes $\left(P>E_{\mathrm{T}}\right)$ from runoff-consuming sink regimes $\left(E_{\mathrm{T}}>P\right)$, where sources of water for $E_{\mathrm{T}}$ include local precipitation, landscape inflows, and (on a transient basis) storage depletion. A hydrologic unit near the headwater-source end member (Fig. 1c) has an SSI near +1 and an et / $p$ near 0 ; a hydrologic unit near the terminal sink end member has an SSI near -1 and an et $/ p \gg 1$, approaching the local value of the aridity index (the long-termaverage ratio of potential evapotranspiration $\left[\mathrm{PE}_{\mathrm{T}}\right]$ to $P$ ).

Note that et/ $p$ is mathematically equivalent to the classical catchment-evapotranspiration ratio (actual $E_{\mathrm{T}} / P$; Fig. 1d) under runoff-generating conditions $\left(P>E_{\mathrm{T}}\right)$ linking our open-system, hydrologic-unit framework to the semiclosed, catchment framework of classical hydroclimatology (Budyko, 1974; Sankarasubramanian and Vogel, 2003). This linkage is expressed graphically in Fig. 1c and d. The top, horizontal axis of our two-dimensional (2-D) regime space $(p=1$; Fig. 1c) duplicates the one-dimensional axis in Fig. 1d. However, the second, vertical dimension of our space $(p<1)$ allows runoff-consuming regimes $\left(E_{\mathrm{T}}>P\right.$; et $/ p>1$ ) to be characterized as well. 
Table 2. Indicators of terrestrial water availability. $P$, precipitation; $E_{\mathrm{T}}$, evapotranspiration; $\mathrm{PE}_{\mathrm{T}}$, potential evapotranspiration. Landscape inflows and outflows $\left(L_{\text {in }}, L_{\text {out }}\right)$ include both surface and groundwater flows (Fig. 1a). All length per time units $\left(\mathrm{L} \mathrm{T}^{-1}\right)$ are equivalent to $\mathrm{L}^{-3} \mathrm{~L}^{-2} \mathrm{~T}^{-1}$, where $\mathrm{L}^{2}$ refers to the area of the local HU that is receiving or donating water. LR is the mean local runoff during a specified long-term period; other indicators may be defined for a specified period, or time step, of any length.

\begin{tabular}{|c|c|c|c|c|c|}
\hline Indicator & $\begin{array}{l}\text { Simple } \\
\text { definition }\end{array}$ & $\begin{array}{l}\text { Expanded } \\
\text { definition }\end{array}$ & $\begin{array}{l}\text { Measurement } \\
\text { units }\end{array}$ & $\begin{array}{l}\text { Permissible } \\
\text { range }\end{array}$ & Reference \\
\hline Local runoff, LR & $P-E_{\mathrm{T}}$ & same & $\mathrm{LT}^{-1}$ & $\geq 0$ & Bras (1989) \\
\hline Landscape inflow, $L_{\text {in }}$ & $L_{\text {in }}$ & same & $\mathrm{LT}^{-1}$ & $\geq 0$ & this paper \\
\hline $\begin{array}{l}\text { Landscape outflow, } \\
L_{\text {out }}\end{array}$ & $L_{\text {out }}$ & same & $\mathrm{LT}^{-1}$ & $\geq 0$ & this paper \\
\hline $\begin{array}{l}\text { Total storage } \\
\text { change, } \mathrm{d} S_{\mathrm{T}} / \mathrm{d} t\end{array}$ & $\mathrm{~d} S_{\mathrm{T}} / \mathrm{d} t$ & $\left(P+L_{\mathrm{in}}\right)-\left(E_{\mathrm{T}}+L_{\mathrm{out}}\right)$ & $\mathrm{LT}^{-1}$ & $\begin{array}{l}\text { positive, } \\
\text { negative, or zero }\end{array}$ & Bras (1989) \\
\hline Aridity index, AI & $\mathrm{PE}_{\mathrm{T}} / P$ & same & dimensionless & $\geq 0$ & Budyko (1974) \\
\hline $\begin{array}{l}\text { Catchment } \\
E_{\mathrm{T}} \text { ratio, } E_{\mathrm{T}} R\end{array}$ & $E_{\mathrm{T}} / P$ & same & dimensionless & $0 \leq E_{\mathrm{T}} R \leq 1$ & Budyko (1974) \\
\hline Runoff ratio, RR & $1-\left(E_{\mathrm{T}} / P\right)$ & same & dimensionless & $0 \leq \mathrm{RR} \leq 1$ & Budyko (1974) \\
\hline $\begin{array}{l}\text { Total water } \\
\text { availability, TWA }\end{array}$ & - & $\begin{array}{l}\max \left\{\left(P+L_{\text {in }}\right)\right. \\
\left.\left(E_{\mathrm{T}}+L_{\text {out }}+\left[-\mathrm{d} S_{\mathrm{T}} / \mathrm{d} t\right]\right)\right\}\end{array}$ & $\mathrm{LT}^{-1}$ & $\geq 0$ & this paper \\
\hline $\begin{array}{l}\text { Normalized } \\
\text { precipitation, } p\end{array}$ & $p$ & $P /$ TWA & dimensionless & $0 \leq p \leq 1$ & this paper \\
\hline $\begin{array}{l}\text { Normalized } \\
\text { evapotranspiration, et }\end{array}$ & et & $E_{\mathrm{T}} / \mathrm{TWA}$ & dimensionless & $0 \leq \mathrm{et} \leq 1$ & this paper \\
\hline $\begin{array}{l}\text { Normalized total } \\
\text { storage change }\end{array}$ & $\mathrm{d} s_{\mathrm{T}} / \mathrm{d} t$ & $\left(\mathrm{~d} S_{\mathrm{T}} / \mathrm{d} t\right) / \mathrm{TWA}$ & dimensionless & $-1 \leq \mathrm{d} s_{\mathrm{T}} / \mathrm{d} t \leq 1$ & this paper \\
\hline $\begin{array}{l}\text { Source-sink index, } \\
\text { SSI }\end{array}$ & $p-\mathrm{et}$ & $\left(P-E_{\mathrm{T}}\right) / \mathrm{TWA}$ & dimensionless & $-1 \leq \mathrm{SSI} \leq 1$ & this paper \\
\hline $\begin{array}{l}\text { Green-blue index, } \\
\text { GBI }\end{array}$ & $(p+\mathrm{et}) / 2$ & $\begin{array}{l}\left(P+E_{\mathrm{T}}\right) /\left(P+E_{\mathrm{T}}+L_{\mathrm{in}}\right. \\
\left.+L_{\text {out }}\right)\end{array}$ & dimensionless & $0 \leq \mathrm{GBI} \leq 1$ & this paper \\
\hline $\begin{array}{l}\text { Hydrologic unit } \\
E_{\mathrm{T}} \text { ratio, et } / p\end{array}$ & et $/ p$ & $E_{\mathrm{T}, \mathrm{HU}} / P$ & dimensionless & $\geq 0$ & this paper \\
\hline
\end{tabular}

\section{Methods}

\subsection{Continental water-balance model and data sources}

An existing, distributed water-balance model of the conterminous USA (McCabe and Markstrom, 2007) was modified to simulate baseline, mean-annual hydroclimatic regimes for the 1896-2006 period. The modified model allows for the consumption of groundwater and surface water in river corridors and terminal sink basins; it was developed by coupling a simple water-balance model to a river network. The modified model was applied to the 53400 networked hydrologic units defined by the individual segments of the river file 1 (RF1) river network (Nolan et al., 2002). Flow generated in the hydrologic units is routed downstream through the river network. Using the terms introduced in this paper, the $L_{\text {in }}$ volume for a hydrologic unit equals the sum of $L_{\text {out }}$ volumes from the immediately upgradient hydrologic units. Depending on climatic conditions, runoff consumption in a stream corridor or terminal-sink hydrologic unit (i.e., evapotranspiration of landscape inflows $\left.\left[L_{\text {in }}\right]\right)$ is allowed to occur to satisfy the evapotranspiration demand of a hydrologic unit. Note that $L_{\text {in }}$ is a lumped term, comprising both groundwater and surface-water inflows to a hydrologic unit; see Fig. 1a, and Supplement.

The water-balance model uses a monthly accounting procedure based on concepts originally presented by Thornthwaite (1948) and described in detail by McCabe and Markstrom (2007). Climate inputs to the model are mean monthly temperature and monthly total precipitation from the PRISM (Parameter-elevation Regressions on Independent Slopes Model) modeling system, for the 1896-2006 period (di Luzio et al., 2008). The water-balance model tracks 
major components of the hydrologic unit water budget including precipitation, $\mathrm{PE}_{\mathrm{T}}$, actual $E_{\mathrm{T}}$, snow accumulation, snowmelt, soil moisture storage, and runoff delivered to the stream network.

As streamflow is routed through the river network, some portion of the flow can be "lost" in a downstream hydrologic unit through evapotranspiration. The quantity of lost streamflow is assumed to be a function, in part, of excess $P_{T}$ in the hydrologic unit, which is defined as the $E_{\mathrm{T}}$ that is in excess of actual $E_{\mathrm{T}}$ computed by the water-balance model. The model assumes that excess $\mathrm{PE}_{\mathrm{T}}$ within a river corridor places a demand on water entering the hydrologic unit from upstream flow and that the river corridor is $30 \%$ of the total hydrologic unit area. Furthermore, it is assumed that the amount of upstream flow that can be diverted to satisfy excess $\mathrm{PE}_{\mathrm{T}}$ is limited to $50 \%$ of the total upstream flow. The percentages used in the calculations were determined by subjective, trialand-error calibration of the model to measured streamflow in arid-region river corridors that are known to lose water due to ground- and surface-water evapotranspiration in the downstream direction. Runoff consumption in a hydrologic unit occurs when locally generated streamflow, computed from the water-balance model, is less than the computed streamflow loss. For hydrologic units that are specified as terminal sinks in the RF-1 network, the total evapotranspiration from the hydrologic unit is set equal to total water available to the unit on a long-term-mean basis $\left(P+L_{\text {in }}\right)$. In certain arid and semiarid hydrologic units of the conterminous USA, where no RF-1 stream reaches have been defined, we assume that long-term-mean precipitation (obtained from the PRISM data set) equals total $E_{\mathrm{T}}$ from each unit, that $L_{\mathrm{in}}=L_{\text {out }}=0$, and that $p=\mathrm{et}=1$. See Eqs. (1), (2), and associated text for definitions of terms.

The performance of the linked water-balance and rivernetwork model was evaluated by comparing estimated streamflow to measured streamflow for river corridors with a complete data record for water-year 2004 (October 2003September 2004). The correlation between estimated and measured mean-annual flow for all conterminous USA streamgages was 0.99. Correlation-coefficient values for selected river corridors with runoff-consuming hydrologic units were 0.75 (Colorado River), 0.98 (Missouri River), 0.99 (Yellowstone River), and 0.70 (Humboldt River). The lower correlation coefficients for some of the river corridors likely reflect the simplifying assumptions concerning runoff consumption used in this study (described above), the use of a lumped, landscape-flow approach (cf. Supplement), and the potential effects of human water use (Weiskel et al., 2007), which were not explicitly considered in this analysis.

\subsection{Transient watershed model}

A published watershed model of the Ipswich River basin, Massachusetts, USA (Zarriello and Ries, 2000), developed using the Hydrological Simulation Program-FORTRAN
(HSPF) code, was used to illustrate temporal variation in hydroclimatic regimes. The published model was calibrated to observed daily streamflows at two long-term US Geological Survey streamgages in the basin (gages 01101500 and 01102000). For the purpose of our analysis, hourly model output values for the 1961-1995 period were aggregated to produce 420 consecutive monthly values of all water-balance components (Eq. 1) for a selected model hydrologic unit in the upper basin (Reach 6, Lubbers Brook). The resulting normalized regime indicators were then calculated and plotted at the monthly, median-monthly, and mean-annual timescales for the period of interest.

\section{Results}

\subsection{Spatial regime variation, conterminous USA}

In order to illustrate continental-scale spatial variation of long-term, mean-annual hydroclimatic regimes (both within and between individual river basins), we chose basins from humid, semiarid, and humid-to-arid regions of the conterminous USA for analysis. Maps of et/ $p$, and plots of et vs. $p$ are used to demonstrate spatial variation in mean conditions for the 20th century (Fig. 2a, b, d, e; see Fig. 1e for locations).

The plotted regimes (Fig. 2d) of the humid Connecticut River basin, New England (Fig. 2a), showed a roughly linear pattern across the regime space, from headwaters $(p=1)$ to mouth $(p=0.0014)$. Runoff-generating regimes were indicated for the entire region; et/ $p$ ranged from 0.28 to 0.64 , as a function of elevation and latitude. Green flows exceeded blue flows (GBI > 0.5) in $55 \%$ of the 349 hydrologic units. Such moderate-source regimes (et/ $p$ near 0.5 ) are common in humid, temperate regions where locally generated runoff is an important component of the landscape water balance.

The 150 hydrologic units of the semiarid Loup River basin, a subbasin of the Platte Basin in central Nebraska (Fig. 2a, d), had a median et/ $p$ ratio almost twice as large as the Connecticut Basin ratio (0.94 vs. 0.51). The ratios also varied over a narrower range (0.85-1.05). Consistent with the semiarid climate, $73 \%$ of the hydrologic units in the Loup Basin were dominated by green regimes and $6.7 \%$ were simulated as runoff-consuming on a long-term-average basis ( $E_{\mathrm{T}}>P$, with $L_{\text {in }}$ meeting a portion of the evapotranspiration demand). The Loup River basin illustrates the lowrunoff, $P$-and- $E_{\mathrm{T}}$-dominated hydroclimatic regimes common to the semiarid steppes, savannas, and arid high deserts that comprise most of the world's dryland ecosystems on all continents, from the subtropics to the midlatitudes (Reynolds et al., 2007).

The regimes of the $310000 \mathrm{~km}^{2}$ Great Basin of the intermountain USA (Figs. 1e; 2b, e) contrast markedly with the relatively uniform regimes of New England and the central High Plains. The Great Basin's headwater catchments ( $p=1$, top axis, Fig. 2e) and other high elevation hydrologic 

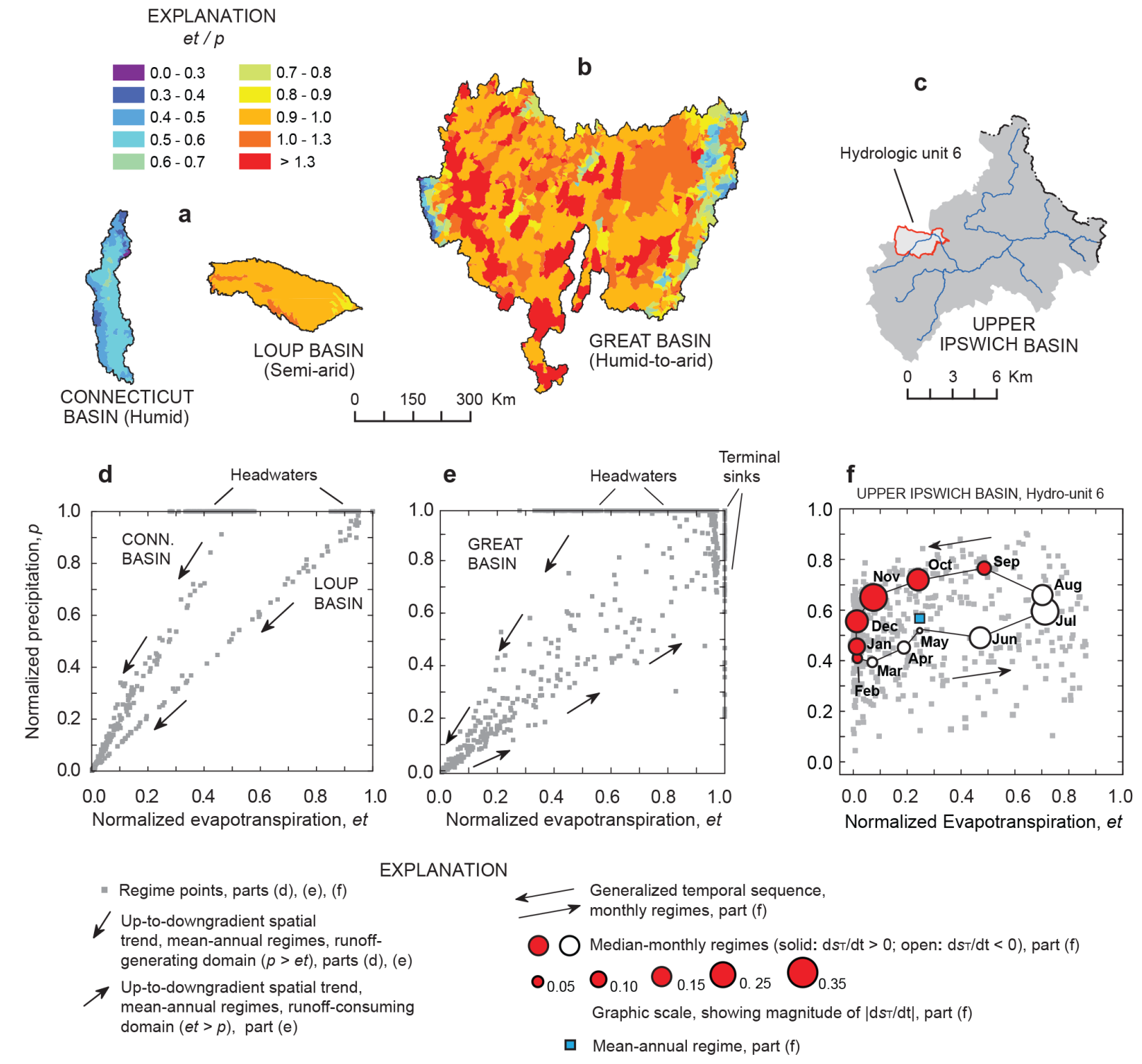

Figure 2. Spatial variation of hydroclimatic regimes (1896-2006), shown by maps (a, b) of hydrologic-unit-evapotranspiration ratio (et/ $p$ ) and hydroclimatic-regime scatter plots (d, e) of selected USA basins: Connecticut River basin, New England ( $n=349)$; Loup River basin, Nebraska $(n=150)$; and Great Basin, intermountain USA $(n=908)$. Temporal variation of monthly $(n=420)$ median-monthly $(n=12)$, and mean-annual $(n=1)$ hydroclimatic regimes (1961-1995) for hydrologic unit 6, Ipswich River basin, New England (c, f).

units near the eastern and western boundaries of the basin were runoff-generating, yet $29 \%$ of the basin's 908 hydrologic units, and $34 \%$ of its total area was runoff-consuming. The Great Basin is endorheic, or closed, under current climate; all landscape flow paths ultimately terminate in lowland sinks where $E_{\mathrm{T}}$ is the only outflow term in the water balance (et $=1$, right-vertical axis, Fig. 2e). Temporally averaged et $/ p$ varied 17 -fold across the basin during the 20th century, from 0.28 in the High Sierras (western boundary) to 4.6 in Slough Creek in the central part of the basin (site 3 in Figs. 1c, 2e, and Table 1). The Great Basin is the major North American example of a closed, humid- mountain-to-arid-lowland domain with extreme spatial variation in hydroclimatic regimes. Comparable large endorheic systems include the closed basins of western China, the Aral and Caspian seas in central Asia, Lake Chad in central Africa, Lake Titicaca in Peru/Bolivia, and Lake Eyre in Australia (Zang et al., 2012; Micklin, 2010; Lemoalle et al., 2012).

Runoff-consuming regimes are also found along arid river corridors in open (exorheic) basins, such as the downstream portions of the Colorado, Nile, Yellow, and Indus river basins. In such settings, blue-water evaporation rates are high and transpiration by riparian vegetation can be 
quantitatively important for the landscape water balance (Nagler et al., 2009; Karimi et al., 2013). Such runoffconsuming landscapes (long-term et $/ p>1$ ), comprise a subset of the world's drylands with distinct hydroclimatic, ecological, and geochemical characteristics (Tyler et al., 2006; Nagler et al., 2009).

\subsection{Temporal regime variation, Upper Ipswich Basin, New England, USA}

Regime plots may also be used to display temporal regime variation, including storage dynamics, for individual hydrologic units over a range of timescales. Using a previously published watershed model, we analyzed regime variations in a selected hydrologic unit (Fig. 2c) in the Upper Ipswich River basin, New England (see Methods Sect. 3.2). Regimes are plotted for the 420 consecutive months of the simulation period (1961-1995), and are aggregated to the medianmonthly and mean-annual timescales (Fig. 2f). Simulated monthly et $/ p$ varied by about 7000 -fold and GBI by 30 -fold over the period. Most of this variation can be attributed to the strongly seasonal $E_{\mathrm{T}}$ cycle of the northeastern USA, since monthly precipitation is relatively constant year-round in the region (Vogel et al., 1999).

On a median-monthly basis over the study period, this hydrologic unit generated runoff from September to May, and consumed runoff from June to August. Blue fluxes ( $\left.L_{\text {in }}, L_{\text {out }}\right)$ dominated the water balance from October to June, while green fluxes $\left(P, E_{\mathrm{T}}\right)$ dominated from July to September. Accretion of total storage occurred from September to February, and depletion of storage from March to August. Large seasonal and interannual hydroclimatic variation is indicated (Fig. 2f) in a region where spatial variation in hydroclimate is modest on a mean-annual basis (Vogel et al., 1999). The size, shape, and orientation of the regime point-cloud and medianmonthly polygon (Fig. 2f) illustrate the seasonal dynamics of the various water-balance components $\left(P, E_{\mathrm{T}}, L_{\mathrm{in}}, L_{\mathrm{out}}\right.$, $\left.\mathrm{d} S_{\mathrm{T}} / \mathrm{d} t\right)$ and capture the hydrologic functioning of this hydrologic unit over the 35-year period of interest.

\section{Discussion}

\subsection{Implications for water-resource assessment}

Classical hydroclimatic indicators such as local runoff, the aridity index, and the catchment evapotranspiration ratio (Table 2) have been used for decades in water-resource assessments at all spatial scales (Budyko, 1974; Gebert et al., 1987; Vogel et al., 1999; Sankarasubramanian and Vogel, 2003; Milly et al., 2005). The regime indicators of this paper complement these classical indicators and address some of their limitations as indicators of water availability. Below, we demonstrate how our new indicators (total water availability, the green-blue index, and the hydrologic-unit- evapotranspiration ratio) address the limitations of two classical indicators - local runoff and the aridity index.

\subsubsection{Local runoff, total water availability, and the green-blue index}

Maps of local runoff, constructed by contouring long-term, temporally averaged runoff $\left(P-E_{\mathrm{T}}\right)$ values assigned to the centroids of gaged catchments (e.g., Gebert et al., 1987) effectively capture one aspect of hydroclimatic variation in runoff-generating regions; local runoff varied $\sim 3300$ fold across the conterminous USA on a long-term, meanannual basis during the 20th century (Figs. 3a; S1a in the Supplement). However, equating water availability for humans and ecosystems with local runoff can hinder the basic understanding of water availability (cf. Falkenmark and Rockström, 2004). A runoff-focused approach minimizes the role of precipitation as a source of water to landscapes, especially in semiarid regions with moderate precipitation ( 250-500 $\mathrm{mm} \mathrm{yr}^{-1}$ ), comparably high evapotranspiration, and very low (or zero) runoff (e.g., Table 1 , site 2 ). In addition, maps of local runoff (Fig. 3a) neglect the networked character of water availability, that is, the role of hydrologic position (see Appendix A) as well as local climate in governing the total amount of water available as inflow to a landscape hydrologic unit. These limitations are addressed by our newly introduced TWA indicator (Eq. 2, Figs. 3b, S1a), and dimensionless GBI (Figs. 3d, S1c). The TWA indicator incorporates both vertical (green), and horizontal (blue) components of inflow to a hydrologic unit, in units of volumetric inflow to the hydrologic unit per unit area of the receiving hydrologic unit $\left(\mathrm{L}^{-3} \mathrm{~L}^{-2} \mathrm{~T}^{-1}\right.$, or $\left.\mathrm{L} \mathrm{T}^{-1}\right)$. Because both precipitation and landscape inflows are incorporated into TWA, it is an exceptionally sensitive indicator, and can vary spatially over a large range. In the conterminous USA, for example, TWA varied spatially by nearly 5 orders of magnitude ( $\sim 450000$-fold) on a mean-annual basis during the 20th century (Figs. 3b, S1a). At the low end of the TWA spectrum are found arid upland hydrologic units with low precipitation and no significant blue-water inflow (TWA $<10^{2} \mathrm{~mm} \mathrm{yr}^{-1}$ ); at the high end, hydrologic units at the mouths of large rivers (TWA $>10^{6} \mathrm{~mm} \mathrm{yr}^{-1}$, essentially all from blue-water inflow).

We introduce the GBI (Fig. 3c) as a dimensionless counterpart to TWA. It quantifies the relative magnitudes of total green $\left(P+E_{\mathrm{T}}\right)$ versus total blue $\left(L_{\mathrm{in}}+L_{\text {out }}\right)$ fluxes experienced by a hydrologic unit (Table 2). The GBI was also found to be highly sensitive, varying spatially across the conterminous area by $\sim 24000$-fold (Fig. S1c). Note that the GBI is best viewed in tandem with precipitation (Figs. 3c, S1b). This allows upland semiarid $\left(\sim 250-500 \mathrm{~mm} \mathrm{yr}^{-1}\right)$ and desert $\left(<250 \mathrm{~mm} \mathrm{yr}^{-1}\right)$ landscapes with equally high GBI values to be distinguished from each other. 
a Local runoff $\left(\mathrm{mm} \mathrm{yr}^{-1}\right)$

$(P-E T)$

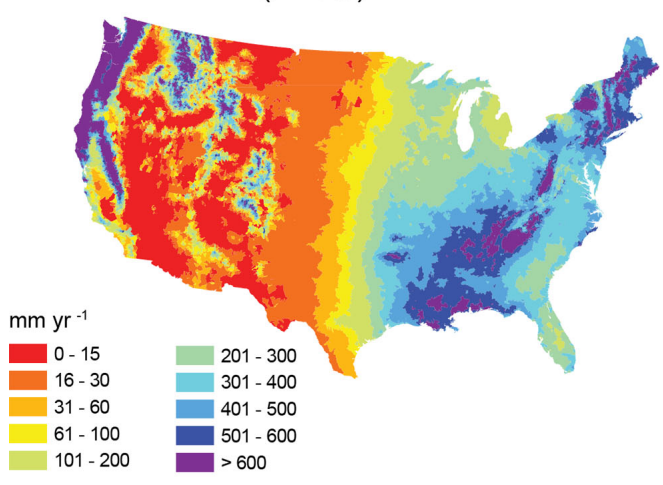

C

Precipitation (mm yr -1)
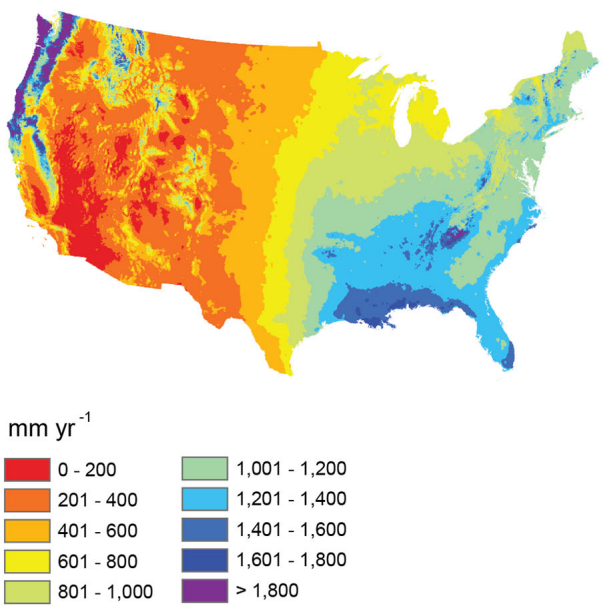

e

Aridity index $\left(P E_{T} / P\right)$ (dimensionless)

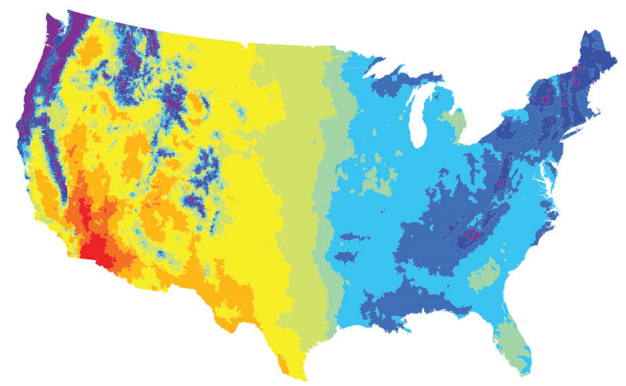

b Total water availability $\left(\mathrm{m} \mathrm{yr}^{-1}\right)$

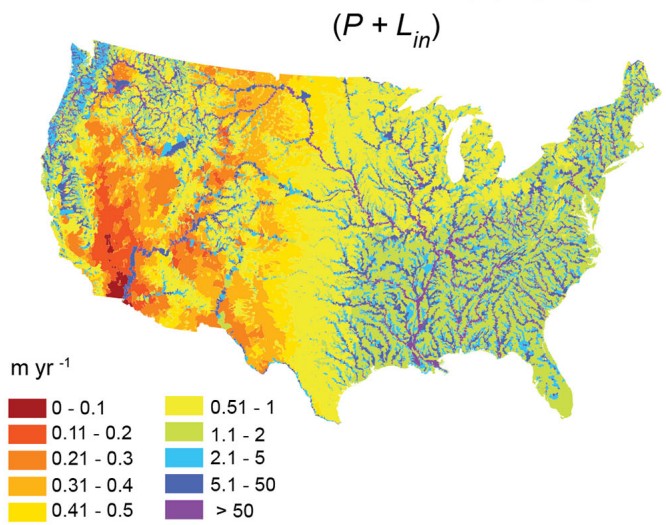

d

(dimensionless)
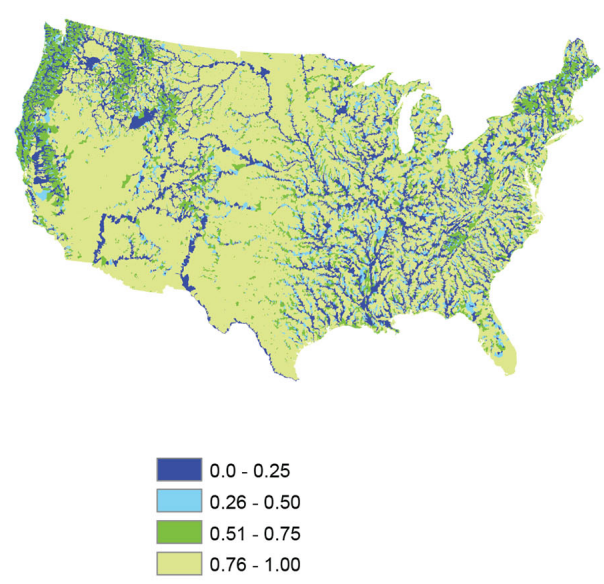

f

Hydrologic-unit $E_{T}$ ratio, (et / p) (dimensionless)
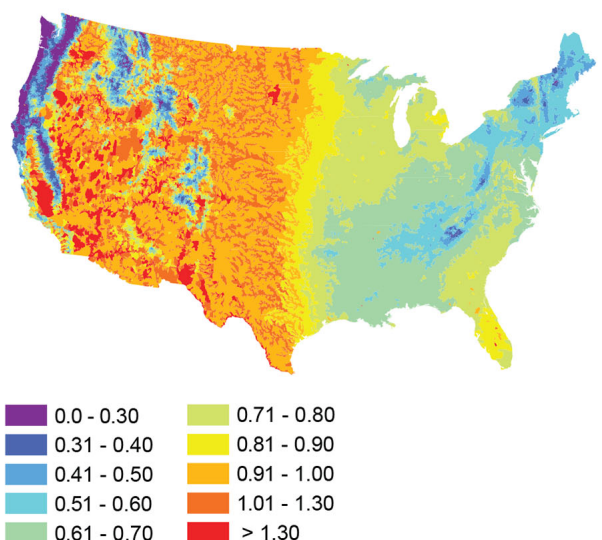

Figure 3. Classic (a, c, e) and newly introduced $(\mathbf{b}, \mathbf{d}, \mathbf{f})$ indicators of terrestrial water availability for 53400 networked hydrologic units of the conterminous USA, on a mean-annual basis for 1896-2006. See text and Table 2 for indicator definitions. (a) Local runoff (mm yr ${ }^{-1}$ ), (b) total water availability $\left(\mathrm{m} \mathrm{yr}^{-1}\right)$, (c) precipitation $\left(\mathrm{mm} \mathrm{yr}^{-1}\right)$, (d) green-blue index (dimensionless), (e) aridity index (dimensionless), and (f) hydrologic-unit-evapotranspiration ratio (et/ $p$, dimensionless). 


\subsubsection{Aridity index and the hydrologic-unit $E_{\mathrm{T}}$ ratio $($ et $/ p)$}

The aridity index (AI), the long-term-average ratio of potential evapotranspiration to precipitation at a location $\left(\mathrm{PE}_{\mathrm{T}} / P\right)$ is commonly used to show spatial variation in potential energy available for evapotranspiration (Sankarasubramanian and Vogel, 2003), estimate actual evapotranspiration (Budyko, 1974), and map the global distribution of drylands (UNEP, 1997). The main limitation of the aridity index (Figs. 3e, S1d) is that it fails to distinguish two basic dryland types: (a) uplands where $E_{\mathrm{T}}$ demand is met strictly by soil moisture derived from local precipitation; and (b) runoffconsuming lowlands where $E_{\mathrm{T}}$ demand is met by a combination of local precipitation, as well as groundwater and surface water derived from upgradient hydrologic units. The hydrologic-unit-evapotranspiration ratio (et/ $p$; Figs. 3f, S1e) complements AI by quantifying actual rather than potential $E_{\mathrm{T}}$ rates across the full range of $\mathrm{PE}_{\mathrm{T}}$ values found in a region. Maps of et $/ p$ allow for a more realistic representation of runoff-consuming, arid lowlands (both endorheic sinks and runoff-consuming river corridors) than maps of the aridity index alone.

For example, our et/ $p$ map (Fig. 3f) indicates an east-west pattern of weak-sink river corridors in the High Plains of the central USA. When compared to an aridity map of the region (Fig. 3e), the et/ $p$ map suggests that spatial variation in the High Plains actual evapotranspiration in the 20th century was likely governed as much by the local geography of its river corridors - and the availability of blue water from Rocky Mountain-source areas to the west - as it was by longitudinal variations in $\mathrm{PE}_{\mathrm{T}}$ and precipitation alone. It is important to note that the areal extent and magnitude of runoff consumption in a river corridor (under either predevelopment or developed conditions) depends on the spatial scale of averaging. The relatively coarse scale used our continental analysis ( $\sim 138 \mathrm{~km}^{2}$ hydrologic units) may overestimate the spatial extent, and underestimate the local magnitude, of actual runoff consumption by evaporation and by transpiration through riparian vegetation in individual High Plains river corridors. Improved quantification of $E_{\mathrm{T}}$ using remote sensing techniques and other methods could help to address this limitation (Nagler et al., 2009; Karimi et al., 2013; Sanford and Selnick, 2013).

\subsection{Implications for hydrologic classification}

The development of a coherent hydrologic classification system is widely recognized as a critical need within hydrology (McDonnell and Woods, 2004; McDonnell et al., 2007; Sawicz et al., 2011; Toth, 2013; cf. Special Issue on Catchment Classification; Hydrol. Earth Syst. Sci., vol. 15, 2011). However, there is presently no quantitative, generally accepted classification system that both encompasses the world's hydrologic diversity and allows for quantitative spec- ification of hydrologic thresholds and similarities, in a manner comparable to the dimensionless Reynolds and Froude numbers used to classify hydraulic systems (Wagener et al., 2007, 2008). Most researchers have focused their classification efforts on catchments (watersheds, basins) and their hydrologic function (cf. summary by Sawicz et al., 2011). Others have focused on the conceptualization and classification of hydrologic landscapes (Winter, 2001; Wolock et al., 2004), lakes (Martin et al., 2011), or wetlands (Brinson, 1993; Lent et al., 1997).

In this section, we propose a hydrologic classification that uses the water balance of a hydrologic unit, i.e., Eq. (1), as its organizing principle. This approach encompasses both catchments $\left(L_{\text {in }}=0 ; p=1\right)$ and all types of noncatchment systems ( $\left.L_{\text {in }}>0 ; p<1\right)$, such as wetlands, lakes, stream corridors, upland landscape units, and aggregations of hydrologic units (i.e., hydrologic landscapes).

\subsubsection{A new classification of hydroclimatic regimes}

We begin the classification by specifying the local climate $(\mathrm{et} / p)$ of a hydrologic unit during a period of interest. The et $/ p$ indicator is used to define four regime classes (Fig. 4a): strong source (et $/ p<0.5$ ), where locally generated runoff $\left(P-E_{\mathrm{T}}\right)$ exceeds local $E_{\mathrm{T}}$; weak source $(0.5<\mathrm{et} / p<1)$, where local $E_{\mathrm{T}}$ exceeds local runoff $\left(P-E_{\mathrm{T}}\right)$; weak sink $(1<\mathrm{et} / p<2)$, where $P$ exceeds the local consumption of landscape inflows $\left(E_{\mathrm{T}}-P\right)$; and strong sink (et $\left./ p>2\right)$, where $\left(E_{\mathrm{T}}-P\right)$ exceeds $P$. The relative magnitude of green vs. blue fluxes associated with a hydrologic unit, indicated by GBI, is then used to divide each of these four classes into two subclasses: green, where land-atmosphere fluxes $\left(P\right.$ and $\left.E_{\mathrm{T}}\right)$ dominate, and blue, where landscape fluxes ( $L_{\mathrm{in}}$ and $\left.L_{\mathrm{out}}\right)$ dominate the water balance (Fig. 4a).

The boundaries of these classes (source/sink, weak/strong, green/blue) are not arbitrary; each boundary marks a threshold in the value of a continuous, dimensionless, ratio variable (et $/ p$ or GBI). We suggest that these ratio variables represent hydrologic analogues to the Reynolds and Froude numbers of fluid mechanics, as called for by Wagener et al. (2007). For example, just as the Reynolds number (ratio of inertial forces to viscous forces in a fluid) can be used to indicate a critical threshold in a flow regime (transition from laminar to turbulent flow), the dimensionless hydrologic unit $E_{\mathrm{T}}$ ratio, et $/ p$, can be used to indicate a critical threshold in a landscape hydroclimatic regime - the transition from runoff-generating (source) to runoff-consuming (sink) conditions. This transition is an important hydrologic feature of the humid-mountain-to-arid-basin landscapes found on all of the world's continents. 


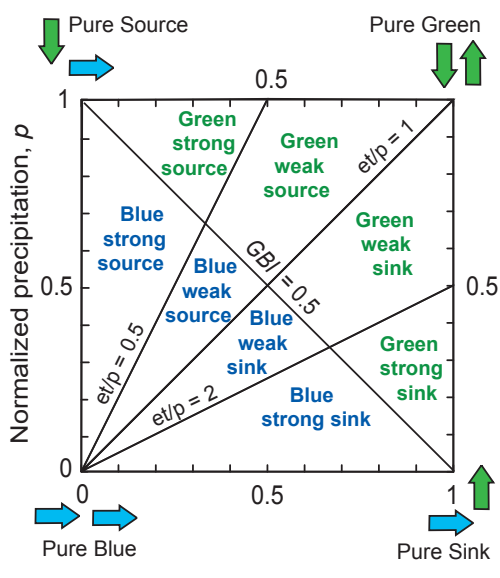

Normalized Evapotranspiration, et

b

\begin{tabular}{rllllll}
\multicolumn{7}{c}{ Percent of conterminous USA area } \\
Strong source \\
Weak source
\end{tabular}

Figure 4. (a) Hydroclimatic regime classification, based on indicators of local climate (hydrologic-unit-evapotranspiration ratio, et $/ p$ ) and relative magnitude of green and blue fluxes (GBI); (b) areas of the conterminous USA covered by regime classes of (a), and by area considered to have zero runoff $(0.99<\mathrm{et} / p<1.01)$.

\subsubsection{Hydroclimatic regime classification: the conterminous USA example}

Our model simulations indicate that weak-source and weaksink hydroclimatic regimes dominated the conterminous USA during the 20th century. We estimate that weak-source and sink regimes covered about 73 and $14 \%$ of the conterminous land area, respectively (Fig. 4b), at the scale of discretization considered (53400 hydrologic units; mean area $=138 \mathrm{~km}^{2}$ ). Strong source and strong sink regimes covered 6.6 and $0.6 \%$ of the conterminous area, respectively, and $6.2 \%$ of the area was considered to generate no runoff (i.e., $0.99<\mathrm{et} / p<1.01$ ) on a long-term, mean-annual basis during this period. Green and blue regimes predominated across 76 and $24 \%$ of the conterminous area, respectively (Fig. 4b). The results for arid regions of the conterminous USA should be considered approximate, because of the simplified model assumptions used in our simulation of runoff consumption (cf. Sect. 3.1).

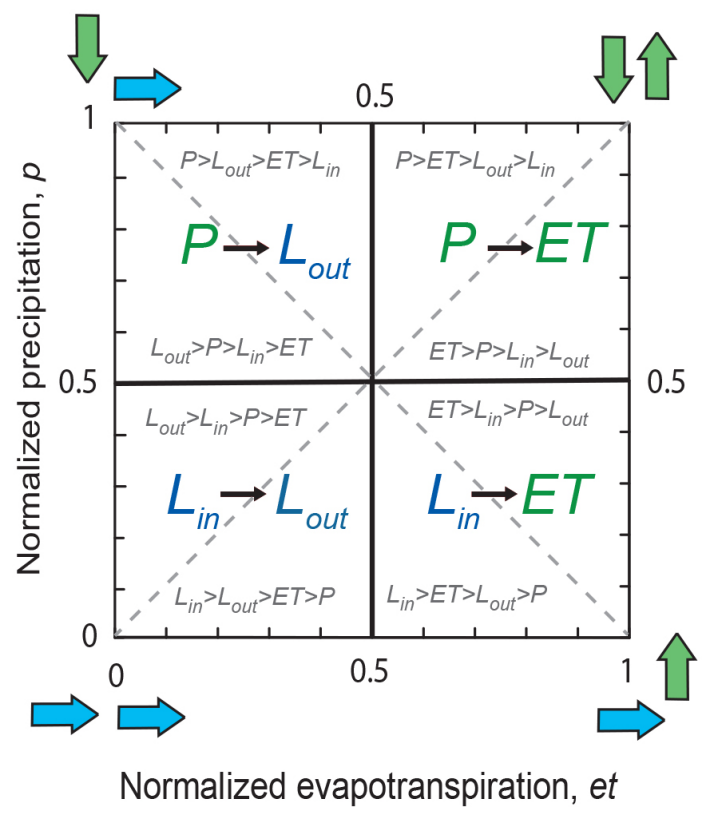

Figure 5. Dominant flow-path-regime classification, for use in water management applications. Blue-and-green arrow combinations at corners of plot depict the four end-member hydroclimatic regimes of Fig. 1c. Dominant flow paths are defined as the largest inflowoutflow combinations characterizing each of the four quadrants of the plot (i.e., $P \rightarrow E_{\mathrm{T}}, L_{\text {in }} \rightarrow L_{\text {out }}, P \rightarrow L_{\text {out }}$, or $L_{\text {in }} \rightarrow E_{\mathrm{T}}$ ). Relative magnitudes of all individual flows are shown in the background of each quadrant. For definitions of all terms, see Table 2.

\subsection{Implications for water management}

Sustainable water management has been defined as the "development and use [of water by humans] in a manner that can be maintained for an indefinite time without causing unacceptable environmental, economic, or social consequences" (Alley et al., 1999). Recently, the close linkage between sustainable land and water management has been emphasized (Falkenmark and Rockström, 2010), as well as the importance of maintaining predevelopment terrestrial biodiversity for sustainable land management (Phalan et al., 2011). Our framework facilitates sustainable land and water management by specifying the dominant water-flow paths (inflowoutflow combinations) and relative magnitudes of individual fluxes experienced by a given hydrologic unit under predevelopment conditions over a period of interest (Fig. 5). Once specified, such flow paths and individual fluxes may then be evaluated as candidates for sustainable human use in a given hydrologic unit, in preference to smaller flow paths and fluxes less capable of supporting long-term human use in the given unit.

\subsubsection{Green and blue regimes}

Consider, for example, the green end-member regimes found in upland portions of the world's drylands (Appendix A), 
where $P \rightarrow E_{\mathrm{T}}$ is the dominant flow path (GBI near 1; site 2 of Table 1 and Fig. 1c). If precipitation is adequate $\left(>\sim 250 \mathrm{~mm} \mathrm{yr}^{-1}\right)$ such landscapes are candidates for dryland farming $-\mathrm{a}$ set of land and water management practices that emphasizes conservation of soils and their moisture holding capacity, runoff control, and minimization of unproductive evaporative losses (Falkenmark and Rockström, 2010). Rainwater harvesting - the short-term capture and storage of local precipitation for subsequent irrigation (Wisser et al., 2010) or residential use (Basinger et al., 2010) - is a green-water management practice that can facilitate dryland farming in semiarid regions with relatively short dry seasons. Note, however, that high seasonal-to-interannual variability and unpredictability of precipitation may strongly constrain the feasibility of dryland agriculture and rainwater harvesting practices in some dryland regions (Brown and Lall, 2006).

By contrast, landscapes approaching the blue end-member regime (GBI near 0; site 4 of Table 1 and Fig. 1c), are dominated by the $L_{\text {in }} \rightarrow L_{\text {out }}$ flow path. Such landscapes are candidates for blue-water domestic, agricultural, and industrial withdrawals $\left(H_{\text {out }}\right)$, wastewater and irrigation return flows $\left(H_{\text {in }}\right)$, and blue-water transfers into or out of the hydrologic unit. Such direct human interactions with the blue-water resources of a hydrounit could be considered sustainable to the degree that they observe the particular flow-alteration and water-quality constraints of the unit's aquatic ecosystems (Poff et al., 1997), and constraints related to depletion or surcharge of blue-water storage in the unit (cf. Weiskel et al., 2007 , for detailed analysis of blue-water-use regimes).

\subsubsection{Source and sink regimes}

Source landscapes function to convert precipitation into blue-water storage and outflow, and are dominated by the $P \rightarrow L_{\text {out }}$ flow path (site 1 , Table 1 ; Fig. 1c). Strong-source mountain landscapes (et $/ p$ near 0; GBI near 0.5 ) serve as the "water towers of the world", and collectively serve the blue-water needs of $\sim 20 \%$ of the human population (Immerzeel et al., 2010). Sustainable land and water management in such settings would likely entail protection from, and mitigation of processes - such as anthropogenic climate warming - that reduce snowpack and glacier storage, or alter the timing, rate, and quality of surface runoff and mountainfront aquifer recharge.

Sink landscapes, by contrast (site 3, Table 1; Fig. 1c; et $/ p \gg 1)$, function to convert blue inflow $\left(L_{\text {in }}\right)$ into green outflow $\left(E_{\mathrm{T}}\right)$ and are dominated by the $L_{\mathrm{in}} \rightarrow E_{\mathrm{T}}$ flow path. Like source landscapes, sink landscapes such as arid river corridors, sink wetlands, and closed-basin lakes typically provide ecosystem services to regions many times larger than the sink itself. For this reason, land and water protection strategies are generally critical to their sustainable management. Blue-water diversions for human use under sink regimes, if not carefully managed, have the potential to cause long-lasting, regional-scale impacts on ecosystems, human health, and human livelihoods. Major examples include Lake Owens, California, USA; the Aral Sea, central Asia; and Lake Chad, central Africa, where system desiccation has been linked, at least in part, to upstream diversions for irrigation and urban use (Groeneveld et al., 2010; Micklin, 2010; Lemoalle et al., 2012). In addition, the practice of sustainable crop irrigation under sink regimes requires careful balancing of blue fluxes into and out of particular hydrologic units, to avoid soil salinization and (or) water logging.

In summary, quantifying the predevelopment hydroclimatic regimes of particular hydrologic units and their temporal variability can assist in the design of sustainable land and water management practices optimized to particular locations. Such practices would reflect (1) the opportunities and constraints of the local climate (indicated by time-varying $P$ and $E_{\mathrm{T}}$ in the hydrologic unit), (2) the hydrologic position (Appendix A) of the unit in the landscape, and (3) the water requirements of local and downgradient ecosystems. The management framework described above is only a starting point; further research is needed to develop and test best practices for land and water management across the full range of hydroclimatic regimes described in this paper.

\subsection{Data requirements, data availability, and future research directions}

In this section, we review the data requirements of the regimes approach, the current availability of these data, and future research directions. Characterization of hydroclimatic regimes requires, at a minimum, data concerning the boundaries and climate of hydrologic units at relevant spatial scales. In certain regions of the world, such as the conterminous USA, these data are relatively abundant at fine scales $\left(<100 \mathrm{~km}^{2}\right)$ and can be incorporated into available waterbalance models (cf. Sect. 3; Supplement). Large areas of the world, however, including most of the world's drylands, have sparse data. Therefore, global data sets are of the utmost importance for characterizing hydroclimatic regimes. For global-scale analyses, hydrologic-unit boundaries are commonly defined in terms of individual rectangular grid cells, derived from digital elevation models (DEMs; e.g., ASTER GDEM v.2; METI/NASA, 2011). DEM grids, typically aggregated to a $0.5^{\circ} \times 0.5^{\circ}$ scale, form the backbone of widely used, spatially distributed, global water-balance models (e.g., Vörösmarty et al., 2000; Döll et al., 2003; Oki and Kanae, 2006; Müller Schmied et al., 2014). Widely available grids of precipitation, temperature, and potential evapotranspiration data (e.g., WorldClim, Hijmans et al., 2005) may be incorporated into a distributed water-balance model to estimate evapotranspiration, generate runoff, and accumulate (or consume) landscape flow in the downgradient direction, through an ordered network of hydrologic units (e.g., Oki and Kanae, 2006; McCabe and Markstrom, 2007; this paper, Sect. 3). It is important to note that hydroclimatic regimes can also be 
simulated for future climate conditions, using output from global climate model (GCM) projections, in a manner similar to the way GCMs have been used to simulate future patterns of local runoff (Milly et al., 2005). Finally, as previously described (Sect. 2.1; Eq. 1; Appendix A), human withdrawals and return flows $\left(H_{\text {in }}\right.$ and $H_{\text {out }}$; Appendix A) may also be incorporated into the regime analysis, if historic data (e.g., Weiskel et al., 2007) or water-use modeling simulations (e.g., Müller Schmied et al., 2014) are available.

Data were available in the present study for spatially detailed, temporally averaged regime characterization at the continental scale. However, a time-varying (transient) analysis of the water balance - allowing for the derivation of seasonal, interannual, and decadal regime variations - was possible only at the scale of an individual hydrologic unit in the present study (Sect. 4.2; Fig. 2c, f). At the continental scale, we were constrained by our simplified model structure and a lack of distributed data concerning total water storage and its response to climate forcing. However, recent developments in both global water-balance modeling and waterstorage data are beginning to overcome this limitation. For example, the recently updated WaterGAP 2.2 global model incorporates water-storage dynamics (Müller Schmied et al., 2014), and could be a useful tool for evaluating temporal trends in hydroclimatic regimes at continental and global scales.

In addition, it should be noted that our study lumps groundwater and surface-water flows into a single "landscape" or blue flow term (Appendix A; Supplement) - consistent with the structure of widely used gridded global water-balance models (e.g., Vörösmarty et al., 2000; Döll et al., 2003; Oki and Kanae, 2006). Recently, however, models have become available at both basin (Markstrom et al., 2008) and global (Müller Schmied et al., 2014) scales which distinguish groundwater and surface-water flows, and (to a greater or lesser extent) their interactions, and their interactions with the unsaturated zone. Such models are able to use newly available, global-scale data on near-surface permeability (Gleeson et al., 2011) and new groundwater-storage estimates derived from the Gravity Recovery and Climate Experiment (GRACE) data set (e.g., Döll et al., 2014). Finally, note that the differentiation of landscape fluxes into surfacewater and groundwater components is fully accommodated by our hydroclimatic regime framework. Such differentiation enables a total of nine $\left(3^{2}\right)$ end-member regimes to be defined from three distinct types of hydrologic-unit inflow and three types of outflow (groundwater, surface-water, and precipitation inflow; and groundwater, surface-water, and evapotranspiration outflow), in contrast to the four $\left(2^{2}\right)$ end-member regimes of the present paper (Fig. 1c).

Several potential research directions for improved understanding of hydroclimatic regimes have been described: (1) simulation of hydroclimatic regimes under future climates; (2) full incorporation of humans into the framework; (3) analysis of seasonal-, interannual-, and decadal- scale regime variations at continental and global scales; and (4) differentiation of groundwater and surface-water components of the hydroclimatic regime. Because of the rapid growth in the types and resolution of gridded global data sets now becoming available, and the continued refinement of global water-balance models, progress on these and other research questions will be greatly facilitated in coming years.

\section{Summary and conclusions}

Classical, runoff-based indicators of terrestrial-water availability have proved useful for characterizing water availability in the world's humid regions. However, they have often hindered our basic hydrologic understanding of dryland environments - the dry-subhumid, semiarid, and arid regions which presently cover nearly half of the global land surface. To address this problem, we introduce a distributed, networked, open-system approach to the landscape water balance. Indicators derived from the resulting framework can be used to characterize humid source areas that generate groundwater and surface-water runoff; high deserts, steppes, and savannas that neither receive nor generate significant runoff; arid lowlands that consume runoff derived from upgradient groundwater and surface-water-source areas; river corridors under all climates; and landscapes with mixed hydroclimatic regimes.

The new framework seeks to deepen our understanding of the full range, or diversity, of terrestrial hydrologic behavior. The framework, based on Eq. (1) of this paper, provides a fully general, quantitative basis for the traditional practice of water-resources assessment (Gebert et al., 1987), and the emerging disciplines of comparative hydrology (Falkenmark and Chapman, 1989; Thompson et al., 2013), hydrologic classification (Wagener et al., 2007), and sustainable land and water management (Falkenmark and Rockström, 2010). The indicators presented are two-dimensional (Fig. 1c) rather than one-dimensional (Fig. 1d), incorporating both the local climate of a hydrologic unit (humid to arid) and its hydrologic position in the landscape (headwater to terminal), at any spatial or temporal scale of interest. Finally, the framework reinterprets the green- and blue-water perspective (Falkenmark and Rockström, 2004) that is gaining increasing international acceptance, and integrates this perspective with the classic, runoff-based understanding of terrestrial water availability. 


\section{Appendix A: Glossary of terms}

- Basin: see catchment.

- Blue water: blue-water flows consist of groundwater and surface-water flows into and out of a hydrologic unit during a period of interest (see landscape inflows and outflows defined below, and shown as $L_{\text {in }}$ and $L_{\text {out }}$ in Fig. 1a). Blue-water storage consists of the saturated portion of total landscape water storage (see below) in a hydrologic unit. Blue-water storage comprises surface water, groundwater, ice, snow, and water stored in human water infrastructure.

- Catchment: the drainage area that contributes water to a particular point along a stream network (Wagener at al., 2007). From the perspective of the present paper, a catchment is a particular type of hydrologic unit, with boundaries defined such that landscape inflows $\left(L_{\mathrm{in}}\right)$ are zero and precipitation is the only type of inflow (Fig. 1b). Although watershed is the preferred term for this type of hydrologic unit in the USA, the equivalent term catchment is generally preferred in Europe and many other parts of the world. Basin is generally the preferred equivalent for large catchments (e.g., the Nile River basin).

- Drylands: drylands are defined by the UNEP (1997) as regions where the long-term ratio of potential evapotranspiration to precipitation (aridity index) is greater than $1.5 ; 41 \%$ of earth's land surface, and $32 \%$ of the conterminous USA meet this definition. Drylands are further classified as dry-subhumid $(\mathrm{AI}=1.5-2)$, semiarid (2-5), arid (5-20), and hyperarid (> 20) (UNEP, 1997).

- Green water: for the purposes of this paper, green-water flows are defined as the vertical, or land-atmosphere flows into and out of a hydrologic unit during a period of interest (Fig. 1a). These flows are (1) precipitation $(P)$, and (2) the sum of evaporation and transpiration (evapotranspiration, $\left.E_{\mathrm{T}}\right)$. This definition differs from that of Falkenmark and Rockström (2004), who equated greenwater flow with $E_{\mathrm{T}}$ outflow only, and considered $P$ to be an undifferentiated inflow. Both Falkenmark and Rockström (2004) and the present paper define green-water storage as soil moisture stored in the unsaturated (or vadose) zone of a landscape.

- Human flows ( $H_{\text {in }}$ and $\left.H_{\text {out }}\right)$ : human withdrawals from a hydrologic unit for local use or export are defined as human outflows $\left(H_{\text {out }}\right)$. Human return flows to a hydrologic unit after local withdrawal and use, or after import and use, are defined as human inflows $\left(H_{\text {in }}\right)$. See Weiskel et al. (2007).

- Hydrologic position: the upgradient/downgradient position of a hydrologic unit in a networked system of hydrologic units. Under runoff-generating conditions $\left(P>E_{\mathrm{T}}\right)$, hydrologic position is indicated by the long-term-average value of normalized precipitation, $p$, and ranges from 1 (headwater location) to 0 at the terminal flow-through location (see end-member diagram, Fig. 1c). Under runoff-consuming conditions $\left(E_{\mathrm{T}}>P\right)$, hydrologic position is indicated by the longterm-average value of the normalized landscape outflow term, $l_{\text {out }}($ i.e., $1-$ et), and ranges from near 1 (flowthrough location, typically found at the mountain front in a humid-to-arid, basin-and-range landscape), to 0 at a downgradient terminal sink location (Fig. 1c).

- Hydroclimatic regime: the hydroclimatic regime is the particular combination of green- and blue-waterbalance components $\left(P, L_{\text {in }}, E_{\mathrm{T}}, L_{\text {out }}, \mathrm{d} S_{\mathrm{T}} / \mathrm{d} t\right)$ that characterize the baseline, predevelopment hydrologic functioning of a hydrologic unit averaged over a specific time period (or step) of interest (for the purposes of the baseline analysis in this paper, human flows $\left(H_{\text {in }}\right.$ and $\left.H_{\text {out }}\right)$, and the artificial component of total landscape storage are set equal to zero.) The water-balance components which comprise the regime may be expressed either in units of $\mathrm{L}^{3}$ per unit area of the hydrologic unit per unit time, $\mathrm{LT}^{-1}$ (Eq. 1), or in the lower-case, dimensionless terms of Eq. (2): $p, l_{\text {in }}$, et, $l_{\text {out }}, \mathrm{d} s_{\mathrm{T}} / \mathrm{d} t$. These terms indicate the relative magnitudes of the water-balance components, as fractions of the total water availability.

- Hydrologic unit: (1) narrow definition: an area of land surface that contributes water to a defined stream reach or segment of coastline (cf. Seaber et al., 1987). (2) Broad definition: a bounded unit of earth's land surface, of any size or shape, which is free to receive inflow from either the atmosphere as precipitation $(P)$ or from upgradient hydrologic units as landscape (groundwater + surface-water) inflow $\left(L_{\text {in }}\right)$. See Fig. 1a and Supplement.

- Landscape inflow $\left(L_{\mathrm{in}}\right)$ : the sum of groundwater and surface-water inflow to a hydrologic unit, from one or more upgradient hydrologic units during a period of interest, in units of $\mathrm{L}^{3}$ per unit area of the hydrologic unit per unit time, or $\mathrm{LT}^{-1}$. See Fig. 1a, Table 2, and Supplement.

- Landscape outflow ( $\left.L_{\mathrm{out}}\right)$ : the sum of groundwater and surface-water outflow from a hydrologic unit to one or more downgradient hydrologic units during a period of interest, in units of $\mathrm{L}^{3}$ per unit area of the hydrologic unit per unit time, or $\mathrm{LT}^{-1}$. See Fig. 1a, Table 2, and Supplement.

- Total landscape water storage $\left(S_{\mathrm{T}}\right)$ : the volume of all water stored in a hydrologic unit - soil moisture, groundwater, surface-water, ice, snow, and artificial 
storage in human water infrastructure - all averaged over a time period (or step) of interest, of any length, in units of $L^{3}$ per unit area, or $L$. (For the purposes of the baseline analysis presented here, the artificial component of $S_{\mathrm{T}}$ is set equal to zero.) Change in total landscape storage $\left(\mathrm{d} S_{\mathrm{T}} / \mathrm{d} t\right)$, averaged over a time step of interest (in units of $\mathrm{L}^{3} \mathrm{~L}^{-2} \mathrm{~T}^{-1}$, or $\mathrm{L} \mathrm{T}^{-1}$ ), may be either positive (storage accretion), negative (storage depletion), or zero (steady state). See Fig. 1a, Table 2, and Eqs. (1) and (2).

- Total water availability (TWA): the total inflow to a hydrologic unit from up to three sources during a time step of interest. The first two sources are precipitation $(P)$ and landscape inflow $\left(L_{\mathrm{in}}\right)$. During periods of depletion of total landscape storage $\left(\mathrm{d} S_{\mathrm{T}} / \mathrm{d} t,<0\right)$, when total outflow from a hydrologic unit $\left(E_{\mathrm{T}}+L_{\text {out }}\right)$ exceeds total inflow $\left(P+L_{\text {in }}\right)$, we define "inflow" from total landscape water storage $\left(-\mathrm{d} S_{\mathrm{T}} / \mathrm{d} t\right.$; a positive quantity) to be a third, transient component of TWA. In mathematical terms, TWA $=\max \left\{\left(P+L_{\mathrm{in}}\right),\left(P+L_{\mathrm{in}}+\left[-\mathrm{d} S_{\mathrm{T}} / \mathrm{d} t\right]\right)\right\}$ for any time step.
- Water availability: water that is present and able to be used by humans or other terrestrial and nonmarineaquatic populations.

- Water scarcity: a condition in which the amount of water available for meeting human and ecosystem needs is insufficient.

- Watershed: see catchment. 


\section{The Supplement related to this article is available online at doi:10.5194/hess-18-3855-2014-supplement.}

Acknowledgements. We thank M. Falkenmark, J. Eggleston, D. Bjerklie, E. Douglas, R. Hooper, D. Armstrong, and two anonymous referees for insights, comments, and discussions. Funding support for this research was provided, in part, by the US Geological Survey National Water Census, an initiative of the US Department of Interior WaterSMART Program.

Edited by: N. Ursino

\section{References}

Alley, W., Reilly, T., and Franke, O.: Sustainability of ground-water resources, US Geol. Surv. Circular 1186, US Geological Survey, Reston, VA, USA, 1999.

Basinger, M., Montalto, F., and Lall, U.: A rainwater harvesting system reliability model based on nonparametric stochastic rainfall generator, J. Hydrol., 392, 105-118, 2010.

Bras, R.: Hydrology, Addison-Wesley, New York, 1989.

Brinson, M. M.: A hydrogeomorphic classification for wetlands, Wetlands Research Program Tech. Rep. WRP-DE-4, US Army Corps of Engineers Waterways Experiment Station, Vicksburg, MS, USA, 1993.

Brown, C. and Lall, U.: Water and economic development: The role of variability and a framework for resilience, Nat. Resour. Forum, 30, 306-317, 2006.

Budyko, M.: Climate and Life, translated by D. H. Miller, Academic Press, San Diego, CA, 1974.

di Luzio, M., Johnson, G., Daly, C., Eischeid, J., and Arnold, J.: Constructing Retrospective Gridded Daily Precipitation and Temperature Datasets for the Conterminous United States, J. Appl. Meteorol. Clim., 47, 475-497, 2008.

Döll, P., Kaspar, F., and Lehner, B.: A global hydrological model for deriving water availability indicators: Model tuning and validation, J. Hydrol., 270, 105-134, 2003.

Döll, P., Müller Schmied, H., Schuh, C., Portmann, F., and Eicker, A.: Global-scale assessment of groundwater depletion and related groundwater abstractions: Combining hydrological modeling with information from well observations and GRACE satellites, Water Resour. Res., 50, 5698-5720, doi:10.1002/2014WR015595, 2014.

Falkenmark, M. and Chapman, T. (Eds).: Comparative hydrology: An ecological approach to land and water resources, United Nations Educational Social \& Cultural Organization, Paris, p. 309, 1989.

Falkenmark, M. and Rockström, J.: Balancing water for humans and nature: The new approach in ecohydrology, Earthscan Publications, London, 2004.

Falkenmark, M. and Rockström, J.: The new blue and green water paradigm: Breaking new ground for water resources planning and management, J. Water Resour. Pl. Manage., 132, 129-132, 2006.
Falkenmark, M. and Rockström, J.: Building water resilience in the face of global change: From a blue-only to a green-blue water approach to land-water management, J. Water Resour. Pl. Manage., 136, 606-610, 2010.

Gebert, W., Graczyk, D., and Krug, W.: Annual average runoff in the United States, 1951-1980, US Geol. Survey Hydrol. Invest. Atlas HA-710, US Geological Survey, Reston, VA, 1987.

Gerten, D.: A vital link: water and vegetation in the Anthropocene, Hydrol. Earth Syst. Sci., 17, 3841-3852, doi:10.5194/hess-173841-2013, 2013.

Gleeson, T., Smith, L., Moosdorf, N., Hartmann, J., Dürr, J., Manning, A., van Beek, L., and Jellinek, A.: Mapping permeability over the surface of the Earth, Geophys. Res. Lett., 38, L02401, doi:10.1029/2010GL045565, 2011.

Groeneveld, D., Huntington, J., and Barz, D.: Floating brine crusts, reduction of evaporation and possible replacement of fresh water to control dust from Owens Lake bed, California, J. Hydrol., 392, 211-218, 2010.

Hagemann, S., Chen, C., Clark, D. B., Folwell, S., Gosling, S. N., Haddeland, I., Hanasaki, N., Heinke, J., Ludwig, F., Voss, F., and Wiltshire, A. J.: Climate change impact on available water resources obtained using multiple global climate and hydrology models, Earth Syst. Dynam., 4, 129-144, doi:10.5194/esd4-129-2013, 2013.

Hijmans, R., Cameron, S., Parra, J., Jones, P., and Jarvis, A.: Very high resolution interpolated climate surfaces for global land areas, Int. J. Climatol., 25, 1965-1978, 2005.

Hoekstra, A., Mekonnen, M., Chapagain, A., Mathews, R., and Richter, B.: Global Monthly Water Scarcity: Blue water footprints versus blue water availability, PLOS ONE, 7, e32688, doi:10.1371/journal.pone.0032688, 2012.

Hoff, H., Falkenmark, M., Gerten, D., Gordon, L., Karlberg, L., and Rockström, J.: Greening the global water system, J. Hydrol., 384, 177-186, 2010.

Immerzeel, W., van Beek, L., and Bierkens, M.: Climate change will affect the Asian water towers, Science, 328, 1382-1385, 2010.

Karimi, P., Bastiaanssen, W. G. M., Molden, D., and Cheema, M. J. M.: Basin-wide water accounting based on remote sensing data: an application for the Indus Basin, Hydrol. Earth Syst. Sci., 17, 2473-2486, doi:10.5194/hess-17-2473-2013, 2013.

Lemoalle, J., Bader, J.-C., Leblanc, M., and Sedick, A.: Recent changes in Lake Chad: Observations, simulations and management options (1973-2011), Global Planet. Change, 80-81, 247254, 2012.

Lent, R., Weiskel, P., Lyford, R., and Armstrong, D.: Hydrologic indices for non-tidal wetlands, Wetlands, 17, 19-28, 1997.

Lo, M.-H. and Famiglietti, J. S.: Irrigation in California's Central Valley strengthens the southwestern U.S. water cycle, Geophys. Res. Lett., 40, 301-306, doi:10.1002/grl.50108, 2013.

Markstrom, S., Niswonger, R., Regan, R., Prudic, D., and Barlow, P., GSFLOW - Coupled ground-water and surface-water flow model based on the integration of the Precipitation-Runoff Modeling System (PRMS) and the Modular Ground-Water Flow Model (MODFLOW-2005), Ch. 6D-1, US Geol. Survey Techniques and Methods, US Geological Survey, Reston, VA, 2008.

Martin, S. L, Soranno, P. A., Bremigan, M. T., and Cheruvelil, K. S.: Comparing hydrogeomorphic approaches to lake classification, Environ. Manage., 48, 957-974, 2011. 
Matalas, N.: Comment on the announced death of stationarity, J. Water Resour. Pl. Manage., 138, 311-312, 2012.

McCabe, G. and Markstrom, S.: A monthly water-balance model driven by a graphical user interface, US Geol. Surv. Open-File Report 2007-1088, US Geological Survey, Reston, VA, 2007.

McDonnell, J. and Woods, R.: On the need for catchment classification, J. Hydrol., 299, 2-3, 2004.

McDonnell, J., Sivapalan, M., Vache, K., Dunn, S., Grant, G., Haggerty, R., Hinz, C., Hooper, R., Kirchner, J., Roderick, M., Selker, J., and Weiler, M.: Moving beyond heterogeneity and process complexity: A new vision for watershed hydrology, Water Resour. Res., 43, W07301, doi:10.1029/2006WR005467, 2007.

METI/NASA.: Advanced Spaceborne Thermal Emission and Reflection Radiometer (ASTER) Global Digital Elevation Model Version 2 (GDEM V2; jointly released by the Japan Ministry of Economy, Trade, and Industry and the USA National Aeronautics and Space Adminstration (NASA), http://asterweb.jpl.nasa. gov/gdem.asp (last access: 16 September 2014), 2011.

Micklin, P.: The past, present, and future Aral Sea, Lake. Reserv. Res. Manage., 15, 193-213, 2010.

Milly, P., Dunne, K., and Vecchia, A.: Global pattern of trends in streamflow and water availability in a changing climate, Nature, 438, 347-350, 2005.

Milly, P., Betancourt, J., Falkenmark, M., Hirsch, R., Kundzewicz, Z., Lettenmaier, D., and Stouffer, R.: Stationarity is dead: Wither water management?, Science, 319, 573-574, doi:10.1126/science.1151915, 2008

Müller Schmied, H., Eisner, S., Franz, D., Wattenbach, M., Portmann, F. T., Flörke, M., and Döll, P.: Sensitivity of simulated global-scale freshwater fluxes and storages to input data, hydrological model structure, human water use and calibration, Hydrol. Earth Syst. Sci. Discuss., 11, 1583-1649, doi:10.5194/hessd-11-1583-2014, 2014.

Nagler, P., Morino, K., Didan, K., Erker, J., Osterberg, J., Hultine, K., and Glenn, E.: Wide-area estimates of saltcedar (Tamarix spp.) evapotranspiration on the lower Colorado River measured by heat balance and remote sensing methods, Ecohydrolgy, 2, 18-33, 2009.

Nolan, J., Brakebill, J., Alexander, R., and Schwarz, G.: ERF1_2 Enhanced River Reach File 2.0, US Geol. Surv. Open-File Report 02-40, US Geological Survey, Reston, VA, 2002.

Oki, T. and Kanae, S.: Global hydrological cycles and world water resources, Science, 313, 1068-1072, 2006.

Phalan, B., Onial, M., Balmford, A., and Green, R.: Reconciling food production and biodiversity conservation: Land sharing and land sparing compared, Science, 333, 1289-1291, 2011.

Poff, N., Allan, J., Bain, M., Karr, J., Prestegaard, K., Richter, B., Sparks, R., and Stromberg, J.: The natural flow regime: A paradigm for river conservation and restoration, Bioscience, 47, 769-784, 1997.

Reynolds, J., Smith, D., Lambin, E., Turner II, B., Mortimore, M., Batterbury, S., Downing, T., Dowlatabadi, H., Fernandez, R., Herrick, J., Huber-Sannwald, E., Jiang, H., Leemans, R., Lynam, T., Maestre, F., Ayarza, M., and Walker, B.: Global desertification: Building a science for dryland development, Science, 316, 847-851, 2007.

Rosner, A., Vogel, R., and Kirshen, P.: A risk-based approach to flood management decisions in a nonstationary world, Water Resour. Res., 50, 1928-1942, doi:10.1002/2013WR014561, 2014.
Röst, S., Gerten, D., Bondeau, A., Luncht, W., Rohwer, J., and Schaphoff, S.: Agricultural green and blue water consumption and its influence on the global water system, Water Resour. Res., 44, W09405, doi:10.1029/2007WR006331, 2008.

Sanford, W. and Selnick, D.: Estimation of evapotranspiration across the conterminous United States using a regression with climate and land-cover data, J. Am. Water Resour. Assoc., 49, 217-230, 2013.

Sankarasubramanian, A. and Vogel, R.: Hydroclimatology of the continental United States, Geophys. Res. Lett., 30, 1363, doi:10.1029/2002GL015937, 2003.

Savenije, H. H. G., Hoekstra, A. Y., and van der Zaag, P.: Evolving water science in the Anthropocene, Hydrol. Earth Syst. Sci., 18, 319-332, doi:10.5194/hess-18-319-2014, 2014.

Sawicz, K., Wagener, T., Sivapalan, M., Troch, P. A., and Carrillo, G.: Catchment classification: empirical analysis of hydrologic similarity based on catchment function in the eastern USA, Hydrol. Earth Syst. Sci., 15, 2895-2911, doi:10.5194/hess-15-28952011, 2011.

Seaber, P. R., Kapinos, F. P., and Knapp, G. L.: Hydrologic Unit Maps [of the United States], US Geol. Survey Water-Supply Paper 2294, US Geological Survey, Reston, VA, p. 63, 1987.

Thompson, S. E., Sivapalan, M., Harman, C. J., Srinivasan, V., Hipsey, M. R., Reed, P., Montanari, A., and Blöschl, G.: Developing predictive insight into changing water systems: useinspired hydrologic science for the Anthropocene, Hydrol Earth Syst. Sci., 17, 5013-5039, doi:10.5194/hess-17-50132013, 2013.

Thornthwaite, C.: An approach toward a rational classification of climate, Geogr. Rev., 38, 55-94, 1948.

Toth, E.: Catchment classification based on characterisation of streamflow and precipitation time series, Hydrol. Earth Syst. Sci., 17, 1149-1159, doi:10.5194/hess-17-1149-2013, 2013.

Tyler, S., Munoz, J., and Wood, W.: The response of playa and sabkha hydraulics and mineralogy to climate forcing, Ground Water, 44, 329-338, 2006.

UNEP - United Nations Environment Programme: World Atlas of Desertification, 2nd Edn., Edward Arnold, London, p. 182, 1997.

Vogel, R.: Hydromorphology, J. Water Resour. Pl. Manage., 137, 147-149, 2011.

Vogel, R., Wilson, I., and Daly, C.: Regional regression models of annual streamflow for the United States, J. Irrig. Drain. Eng.ASCE, 125, 148-157, 1999.

Vörösmarty, C. and Sahagian, D.: Anthropogenic disturbance of the terrestrial water cycle, Bioscience, 50, 753-765, 2000.

Vörösmarty, C., Green, P., Salisbury, J., and Lammers, R.: Global water resources: Vulnerability from climate change and population growth, Science, 289, 284-288, 2000.

Vörösmarty, C., Pahl-Wostl, C., Bunn, S., and Lawford, R.: Global water, the anthropocene, and the transformation of a science, Curr. Opin. Environ. Sustain., 5, 539-550, 2013.

Wagener, T., Sivapalan, M., Troch, P., and Woods, R.: Catchment classification and hydrologic similarity, Geogr. Compass, 1, 901931, 2007.

Wagener, T., Sivapalan, M., and McGlynn, B.: Catchment classification and services - Toward a new paradigm for catchment hydrology driven by societal needs, Encyclopedia of Hydrological Sciences, John Wiley \& Sons, London, 2008. 
Weiskel, P., Vogel, R., Steeves, P., Zarriello, P., DeSimone, L., and Ries, K.: Water-use regimes: Characterizing direct human interaction with hydrologic systems, Water Resour. Res. 43, W04402, doi:10.1029/2006WR005062, 2007.

Winter, T.: The concept of hydrologic landscapes, J. Am. Water Resour. Assoc., 37, 335-349, 2001.

Wisser, D., Frolking, S., Douglas, E., Fekete, B., Schumann, A., Vörösmarty, C.: The significance of local water resources captured in small reservoirs for crop production: A global-scale analysis, J. Hydrol., 384, 264-275, 2010.

Wolock, D. M., Winter, T. C., and McMahon, G.: Delineation and evaluation of hydrologic-landscape regions in the United States using geographic information system tools and multivariate statistical analyses, Environ. Manage., 34, 571-588, 2004.
Zang, C. F., Liu, J., van der Velde, M., and Kraxner, F.: Assessment of spatial and temporal patterns of green and blue water flows under natural conditions in inland river basins in Northwest China, Hydrol. Earth Syst. Sci., 16, 2859-2870, doi:10.5194/hess-162859-2012, 2012.

Zarriello, P. and Ries, K.: A precipitation-runoff model for analysis of the effects of water withdrawals on streamflow, Ipswich River Basin, Massachusetts, US Geol. Surv. Water Resour. Invest. Report. 00-4029, US Geological Survey, Reston, VA, 2000. 